\title{
Microstructure of a Third Generation Snack Manufactured by Extrusion from Potato Starch and Orange Vesicle Flour
}

\author{
Tovar-Jímenez X'1 Aguilar-Palazuelos E , Gómez-Aldapa $\mathrm{CA}^{2}$ and Caro-Corrales $\mathrm{JJ}^{1 *}$ \\ ${ }^{1}$ Posgrado en Ciencia y Tecnología de Alimentos, Universidad Autónoma de Sinaloa, Culiacán, México \\ ${ }^{2}$ Área Académica de Química, Instituto de Ciencias Básicas e Ingeniería, Ciudad del Conocimiento, Hidalgo, México
}

\begin{abstract}
The objective of this work was to evaluate the effect of extrusion on microstructural properties of a third generation snack food expanded by microwaves manufactured from orange vesicle flour, commercial nixtamalized corn flour, and potato starch. A Brabender 20DN laboratory extruder was used to get the pellets (unexpanded extruded products). Viscosity profiles (RVA), scanning electron micrographs (SEM), X-ray diffraction patterns, and thermogram data (DSC) were obtained. Analyses were made on raw materials, unprocessed mixture, extruded pellets, and microwave expanded products to study the native starch structure changes. Analyzes suggest that the snacks obtained by the extrusion process were modified to a desirable microstructure for achieving physicochemical properties necessary for acceptance by the consumer.
\end{abstract}

Keywords: Microstructure; Extrusion; Snack; Biopolymers

\section{Introduction}

Extrusion is a continuous thermo-mechanical process where materials containing biopolymers are plasticized and cooked by the combined action of pressure, heat, and shear stress [1]. This thermomechanical process is very useful in producing low-fat snacks and has the advantage of increasing protein and starch digestibility, solubilizing fiber, inactivating toxins, anti-nutritional factors, and undesirable enzymes, such as lipo-oxygenases and peroxidases [2]. In addition, microwaves have been widely used for expanding this type of snacks and some researches on $3 \mathrm{G}$ snacks have focused on the effect of processing on different physical and physicochemical properties [3,4]. During extrusion, raw materials experience chemical and structural transformations such as starch gelatinization, protein denaturation, complex formation between amylose, lipids and/or proteins, and degradation of pigments and vitamins [5], but starch is the most important component due to the changes it undergoes by the thermal process as it affects expansion and final texture of the extrudate. Starch gelatinization can occur at levels from 12 to $22 \%$ moisture content; however, it has been indicated that at low moisture contents, gelatinization is accentuated because of the high shear stress, the heat generation, and the mechanical disruption of the granules [6]. Lee, et al. [4] mentioned that a partial gelatinization $(\approx 50 \%)$ is necessary for obtaining third generation snack foods (pellets), and a further degradation will reduce the size of sugar chains and thus the product stability after expansion will be lost. However, a lesser degradation will not be enough for opening the starch granules reducing the ability to adsorb water, which serves later as a means for expansion. For these reasons, it is important to know the microstructural changes after the extrusion process and microwave expansion of the pellets. Likewise, in Mexico, the citrus industry generates large amounts of residues that are normally discarded in landfills and left to decompose. Including these residues in technological processes can add value for industry and reduce contamination generated by residue decomposition; thus reducing their impact on ecosystems. Added to this, the use of by-products derived from the citric industry and mainly staple vitamins and fibers contained in the juice vesicle of oranges can be increased improving their functional properties. Dietary fiber acts as a bulking agent, normalizing intestinal motility and preventing diverticular disease. Some types may also be important in lowering serum cholesterol levels, in reducing colonic cancer and in preventing hyperglycemia in diabetic patients [7-9]. The objective of this work was to evaluate the effect of extrusion on microstructural properties of a third generation snack food expanded by microwaves manufactured from orange vesicle flour, commercial nixtamalized corn flour, and potato starch.

\section{Materials and Methods}

\section{Raw material preparation}

Orange vesicles were dried and milled in a hammer mill (Laboratory Mill 3100 Perten, Ireland). Commercial nixtamalized corn flour $10 \%$ (NCF), potato starch $79.9 \%$ (PS), and orange vesicle flour $10 \%$ (OVF) were homogenously and mixed with $0.1 \%$ monoglicerides. This formulation was obtained in preliminary studies.

\section{Extrusion process}

Extrusion was carried out in a laboratory extruder (Brabender 20DN, 8-235-00, Brabender OHG, Duisburg, Germany). A rectangular matrix with internal dimensions of $20 \mathrm{~mm}$ wide $\times 1.0 \mathrm{~mm}$ high $\times$ $100 \mathrm{~mm}$ long was used. Screw speed was $1.08 \mathrm{~Hz}(65 \mathrm{rpm})$, using a 2:1 L:D screw ratio and a feed rate of $33 \mathrm{~g} / \mathrm{min}$ (dry matter), $[0.42 \mathrm{~Hz}$ $(25 \mathrm{rpm})]$. Temperatures at the feed and out zones were 60 and $75^{\circ} \mathrm{C}$ The transition zone temperature was $130^{\circ} \mathrm{C}$ and moisture content was $23 \%$; these conditions were obtained from an optimization process

*Corresponding author: Caro-Corrales JJ, Posgrado en Ciencia y Tecnología de Alimentos, Universidad Autónoma de Sinaloa, Blvd. De las Américas y Josefa Ortiz de Domínguez s/n, Ciudad Universitaria, Culiacán, Sin. C.P. 80000, México, Tel: +52-667713-6615; E-mail: josecaro@uas.edu.mx

Received January 13, 2016; Accepted February 04, 2016; Published February 08, 2016

Citation: Tovar-Jímenez X, Aguilar-Palazuelos E, Gómez-Aldapa CA, CaroCorrales JJ (2016) Microstructure of a Third Generation Snack Manufactured by Extrusion from Potato Starch and Orange Vesicle Flour. J Food Process Technol 7: 563 . doi:10.4172/2157-7110.1000563

Copyright: () 2016 Tovar-Jímenez X, et al. This is an open-access article distributed under the terms of the Creative Commons Attribution License, which permits unrestricted use, distribution, and reproduction in any medium, provided the original author and source are credited. 
Citation: Tovar-Jímenez X, Aguilar-Palazuelos E, Gómez-Aldapa CA, Caro-Corrales JJ (2016) Microstructure of a Third Generation Snack Manufactured by Extrusion from Potato Starch and Orange Vesicle Flour. J Food Process Technol 7: 563. doi:10.4172/2157-7110.1000563

Page 2 of 6

by response surface methodology considering expansion index, bulk density, penetration force, and total carotenoid content [10]. The extruded material was cut manually into approximately $1.5 \mathrm{~cm}$ long pellets, and dried at room temperature for approximately $24 \mathrm{~h}$ until reaching $9-13 \%$ moisture content

\section{Pellet expansion by microwave heating}

Extruded products (pellets of $1.5 \mathrm{~cm}$ long) were expanded in a microwave oven ( $\left.\mathrm{LG}^{\circ}, \mathrm{R}-501 \mathrm{CW}, 900 \mathrm{~W}, 2450 \mathrm{~Hz}\right)$ for $28 \mathrm{~s}$. This condition was determined through expansion kinetics at different heating times [10].

\section{Rapid visco-analyzer}

Viscosity properties were evaluated using a Rapid Visco-Analyzer (RVA, 3C, Newport Scientific PTY Ltd., Sydney, Australia) following the instruction manual and suggestions from Aguilar-Palazuelos, et al. [11]. Two grams of sample were diluted with distilled water to get $28 \mathrm{~g}$ in the sample aluminum cup. Sample was continuously agitated and heated at $50^{\circ} \mathrm{C}$ for $1 \mathrm{~min}$. Temperature was raised to $92^{\circ} \mathrm{C}$ at $5.5^{\circ} \mathrm{C} \mathrm{min}^{-1}$, held at $92^{\circ} \mathrm{C}$ for $5 \mathrm{~min}$, lowered from 92 to $50^{\circ} \mathrm{C}$ at a rate of $-5.6^{\circ} \mathrm{C} \mathrm{min}{ }^{-1}$, and held at $50^{\circ} \mathrm{C}$ for $2 \mathrm{~min}$ (Newport-Scientific 1992). From RVA amylograph profiles, the next viscosities were measured: initial viscosity $\left(\mathrm{V}_{\text {ini }}\right)$, viscosity at $92^{\circ} \mathrm{C}\left(\mathrm{V}_{92}\right)$ (maximum temperature), minimum viscosity $\left(\mathrm{V}_{\min }\right)$ at $92^{\circ} \mathrm{C}$, and final viscosity $\left(\mathrm{V}_{\text {fin }}\right)$ (higher viscosity for the cooling period). From these values, total retrogradation viscosity $\left(\mathrm{V}_{\mathrm{r}}\right)$ (final viscosity minus minimum viscosity) was calculated [12].

\section{Scanning electron microscopy}

Analyses were made in raw materials, unprocessed mixture, extruded pellets, and microwave expanded products, according to methodology described by Zazueta-Morales, et al. [13] and AguilarPalazuelos, et al. [14]. A scanning electron microscope model JSM-6300 was used; a secondary electron detector and electron bombardment at $15 \mathrm{kV}$ were used; samples were placed at high vacuum. The milled samples (60-mesh) were mounted on an aluminum $12 \mathrm{~mm}$ diameter holder, PIN type, previously prepared with carbon conductive double coated tapes and colloidal silver adhesive. Morphologies and particle size were observed.

\section{X-ray diffraction}

Analysis was performed on milled samples which pass through a 60 -mesh sieve $(250 \mu \mathrm{m})$, at moisture content between 9 and $13 \%$. Samples were packed in a glass slide $(0.5 \mathrm{~mm}$ deep) and mounted on a Rigaku X-ray diffractometer (Ultima D/Max-2100, Rigaku Denki Co. Ltd, Japan) according to procedures described by Zazueta-Morales, et al. [13]. Analyses were made in raw materials, unprocessed mixture, extruded pellets, and microwave expanded products, in order to determine the effect of processing on the crystallinity of starches.

\section{Differential scanning calorimetry}

Analyses were performed in raw materials, extruded pellets, and microwave expanded products. A calorimeter (Mettler-Toledo 821 e, Columbus, $\mathrm{OH}$ ) was used following recommendations from Toro-Vazquez, et al. [15]. Samples of about $4 \mathrm{mg}$ were added with $16 \mu \mathrm{l}$ of distilled water and hermetically sealed in aluminum pans. Subsequently, they were vigorously shaken and allowed to stand for $18 \mathrm{~h}$. Pans were heated from 40 to $100^{\circ} \mathrm{C}$ at a heating rate of $5^{\circ} \mathrm{C} / \mathrm{min}$; the heating chamber was vented with nitrogen at a flow rate of $20 \mathrm{ml} /$ min. The enthalpy change, initial temperature (onset), (maximum) peak temperature, and the final temperature were determined, using the software STARe Thermal Analizer.

\section{Results and Discussion}

\section{Rapid visco-analyzer}

Viscosity properties (Table 1) and viscosity profiles (Figure 1) are

\begin{tabular}{|l|c|c|c|c|c|}
\hline \multicolumn{7}{|c|}{ Viscosity (mPa s) } \\
\hline Material & $\mathrm{V}_{\text {ini }}$ & $\mathrm{V}_{92}$ & $\mathrm{~V}_{\text {min }}$ & $\mathrm{V}_{\text {fin }}$ & $\mathrm{V}_{\mathrm{r}}$ \\
\hline NCF & 47 & 3114 & 2191 & 4613 & 2422 \\
\hline PS & 7 & 4809 & 2395 & 2404 & 9 \\
\hline OVF & 37 & 43 & 43 & 49 & 6 \\
\hline Mixture & 7 & 1059 & 981 & 1516 & 535 \\
\hline Pellet & 120 & 133 & 97 & 127 & 30 \\
\hline Expanded & 17 & 58 & 61 & 92.15 & 31.15 \\
\hline
\end{tabular}

Table 1: Initial viscosity $\left(\mathrm{V}_{\text {ini }}\right)$, viscosity at $92^{\circ} \mathrm{C}\left(\mathrm{V}_{92}\right)$, minimum viscosity $\left(\mathrm{V}_{\min }\right)$ at $92^{\circ} \mathrm{C}$, final viscosity $\left(V_{\text {fin }}\right)$, and total retrogradation viscosity $\left(V_{r}\right)$ for nixtamalized corn flour (NCF), potato starch (PS), orange vesicle flour (OVF), unprocessed mixture, extruded pellets, and microwave expanded product.
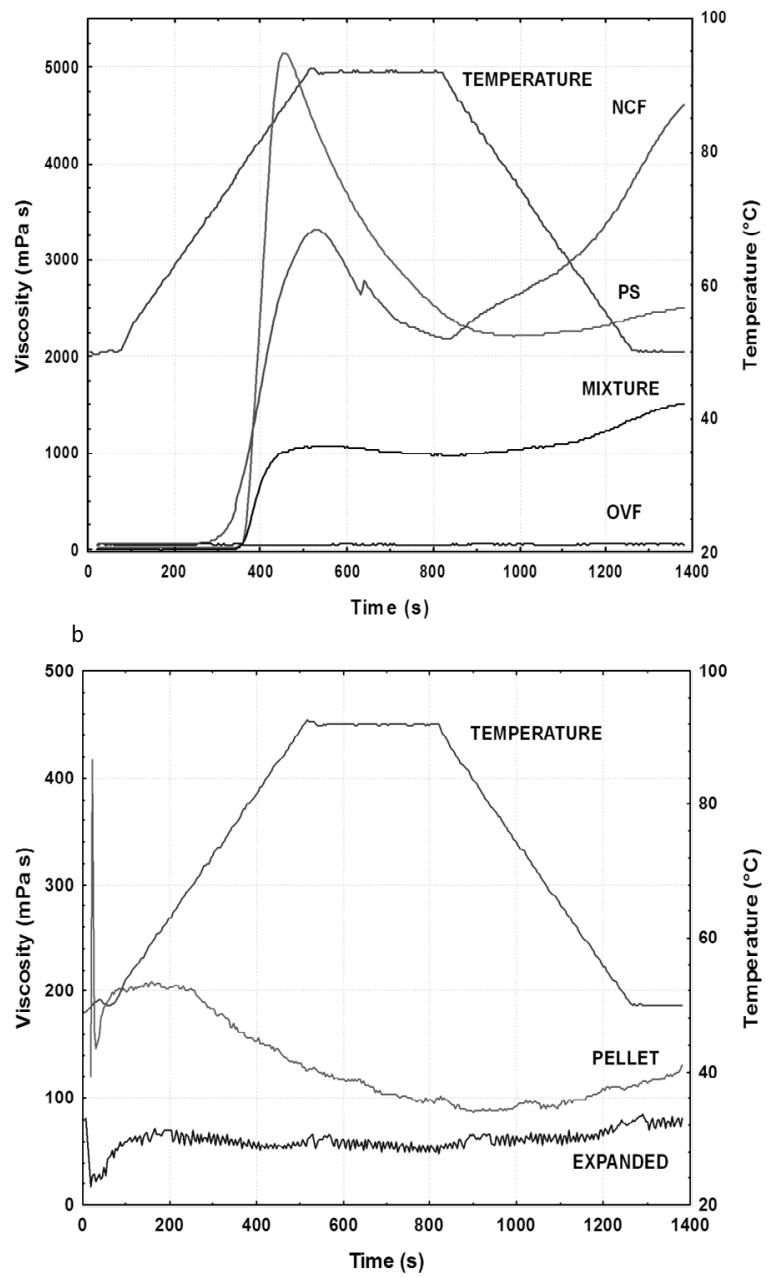

Figure 1: (a) Viscosity profiles for nixtamalized corn flour (NCF), potato starch (PS), orange vesicle flour (OVF), (b) unprocessed mixture, extruded pellets (Pellet), and microwave expanded product (Expanded). 
shown for commercial nixtamalized corn flour (NCF), potato starch (PS), orange vesicle flour (OVF), unprocessed mixture, extruded pellets, and microwave expanded products. Viscosity of nixtamalized corn flour and potato starch increased from $47\left(\mathrm{~V}_{\text {ini }}\right)$ to $3114\left(\mathrm{~V}_{92}\right)$ $\mathrm{mPa} s$ and from 7 to $4809 \mathrm{mPa}$ s, respectively. The difference between NCF and PS viscosity may be due to chemical composition and the previous thermal treatment NCF has undergone; NCF contains gums and during the nixtamalization process, the more susceptible starch granules are partially gelatinized, which are generally the larger ones, remaining the most resistant granules practically unchanged [16]. This may explain why NCF showed a lower viscosity peak $\left(\mathrm{V}_{92}\right)$ of $3114 \mathrm{mPa}$ $\mathrm{s}$ than PS of $4809 \mathrm{mPa}$ s. Maximum viscosity $\left(\mathrm{V}_{92}\right)$ of PS is similar to that reported by Alvis, et al. [17]. Orange vesicle flour did not develop a maximum peak viscosity $\left(\mathrm{V}_{92}\right)$ during heating.

The unprocessed mixture showed a peak viscosity $\left(\mathrm{V}_{92}\right)$ of 1059 $\mathrm{mPa}$ s; this lower viscosity, compared to NCF and PS viscosity, may be due to the presence of fiber, affecting the development of viscosity and the type of link that hinder viscosity development and gel formation. Another reason may be water competition as pericarp can be chemically modified turning fiber from insoluble to soluble and competing for water; also gums in the mixture can be interacting with potato starch. The mixture showed minimum viscosity at $92^{\circ} \mathrm{C}\left(\mathrm{V}_{\min }\right)$ of $981 \mathrm{mPa} \mathrm{s}$, which is lower than that for raw materials; this could be due to fiber affects starch gelatinization as starch molecules become less soluble and tend to aggregate [14].

Nixtamalized corn flour had a $\mathrm{V}_{\min }$ of $2191 \mathrm{mPa}$ s at min 14 and retrogradation started from this point. In like manner, potato starch had a $\mathrm{V}_{\min }$ of $2395 \mathrm{mPa}$ s at min 14 and retrogradation started at minute 18. This time difference for NCF and PS to start retrogradation could be due to amylose retrogradates faster, since as a result of its linear nature and polarity tends to form hydrogen bonds between hydroxyl groups of adjacent molecules (amilose and amilopectin); therefore, they start losing their hydration capability, which yields a partial shrinkage of starch $[16,18]$.

In viscosity profiles for extruded pellets and microwave expanded products (Figure $1 \mathrm{~b}$ ), a slight increase in viscosity during retro gradation was observed, reaching their maximum viscosity at $50^{\circ} \mathrm{C}$, after cooling. This result is similar to that reported by Zazueta-Morale, et al. [13] and Aguilar-Palazuelos, et al. [14]. These authors mentioned that the differences having an extruded starch, relative to a native starch, are the absence of a gelatinization peak, a high initial viscosity and a continuous fall in viscosity from 50 to $92^{\circ} \mathrm{C}$. In addition, during cooling, a slight or no increase in viscosity is obtained, achieving its maximum value at $50^{\circ} \mathrm{C}$. Similarly, the temperature used during extrusion $\left(130^{\circ} \mathrm{C}\right)$ may have caused the dough to become less viscous, allowing the molecules become more susceptible to shearing action. In this way, a higher thermal and mechanical action is achieved, resulting in further degradation of starch and consequently lowering viscosity. This result is similar to that reported by Carvalho, et al. [19], who stated that viscosity is affected by the extrusion temperature (above $80^{\circ} \mathrm{C}$ ) and moisture content. Lee, et al. [4] and Delgado-Nieblas, et al. [20] reported that the best physicochemical properties of third generation products, processed by extrusion, occur when there is a partial degradation of starch, which is confirmed by the above. The physicochemical (functional) properties of extruded starch products depend on the rheology of both the material during processing and the final product, since rheology is highly related to the microstructural changes the product underwent and hence to the ability the material has to interact between the polymeric matrix and the other components of the extruded product.

\section{Scanning electron microscopy}

Figure 2 displays micrographs of raw materials (nixtamalized corn flour, potato starch, and orange vesicle flour) and unprocessed mixture used in the extrusion process. In the unprocessed mixture, different sizes of starch granules are observed, with circular and oval shapes due to the diversity of used materials. In addition, the presence of fiber attached to the starch granules can be seen. The corn flour starch granules are smaller than those of potato, with diameters from 15 to 25 $\mu \mathrm{m}$ and from 15 to $100 \mu \mathrm{m}$, respectively (Figure $2 \mathrm{~b}$ and $2 \mathrm{c}$ ). Similar data were reported by Medina and Salas [21], who reported that corn starch granules have a smaller size $(2-30 \mu \mathrm{m})$ than those of PS $(5-100 \mu \mathrm{m})$. Figure $2 \mathrm{~d}$ shows the fiber fragments of OVF. Micrographs of extruded pellets obtained using the optimal processing conditions $\left(130^{\circ} \mathrm{C}\right.$ and $23 \%$ moisture content) are shown in Figure 3. It can be distinguished the starch granules were melted and plasticized; furthermore, certain channels and holes are observed in the product surface, which may be due to some leakage of water from the material, when leaving the extruder, as reported by Zazueta-Morales, et al. [13]. This type of structure is similar to that reported by Aguilar-Palazuelos, et al. [11] for third generation snacks. Also, it can be seen that pellet fragments are extended (Figure $3 a$ and $3 b$ ); this may be due to an alignment effect of the short chain starches. The extrusion process is able to break the covalent bonds in biopolymers and both the intense structural disruption and mixing facilitate reactions that in other processes are limited [22]. Similarly, it appears that these products are covered by certain particles (Figure 3c), which can be very small size particles of the same material as suggested by Aguilar-Palazuelos, et al. [14]. Figure 4 shows the micrographs of the microwave expanded product. A porous (air cells with thin walls) and extended structure can be viewed (Figure $4 \mathrm{a}$ and $4 \mathrm{~b})$. This structure is very similar to that reported by Lee, et al. [4], with air cells of uniform size, for third generation products expanded by microwaves. This pattern can be caused by a sudden release of pressure generated by steam inside the pellet. Pellets were expanded by microwave, which caused the trapped water inside the extruded began to evaporate, creating an increase in pressure inside the product. When the internal pressure was high enough, the internal structure of the pellet could no longer endure, so that exploded and expanded, causing the air cells of the expanded product were elongated and with smooth surface walls with an approximate size of $1 \mathrm{~mm}$ (Figure $4 \mathrm{a}$ and $4 \mathrm{c}$ ). The holes on the surface could be produced during the escape of steam; this is similar to that reported by Moraru and Kokini [23].

\section{X-ray diffraction}

X-ray patterns of nixtamalized corn flour, potato starch, orange vesicle flour, unprocessed mixture, extruded pellet, and microwave expanded product are shown in Figure 5. Nixtamalized corn flour showed an A-type diffractogram, which is typical for cereal starches, having two main peaks at approximately $2 \theta$ of 16 and $21 \AA$. These peaks have been reported by Zazueta-Morales, et al. [13] and AguilarPalazuelos, et al. [11]. For potato starch and the unprocessed mixture B-type patterns were obtained, which are typical for tubercle starches; the latter behavior was expected as the main component in the mixture was potato starch [20]. Extruded pellets and expanded products showed an amorphous structure. The presence of amorphous structure in extruded materials, at temperatures near $70^{\circ} \mathrm{C}$ and moisture contents above $20 \%$, have been reported by Aguilar-Palazuelos, et al. [11]. These amorphous structures apparently occur because these 
Citation: Tovar-Jímenez X, Aguilar-Palazuelos E, Gómez-Aldapa CA, Caro-Corrales JJ (2016) Microstructure of a Third Generation Snack Manufactured by Extrusion from Potato Starch and Orange Vesicle Flour. J Food Process Technol 7: 563. doi:10.4172/2157-7110.1000563
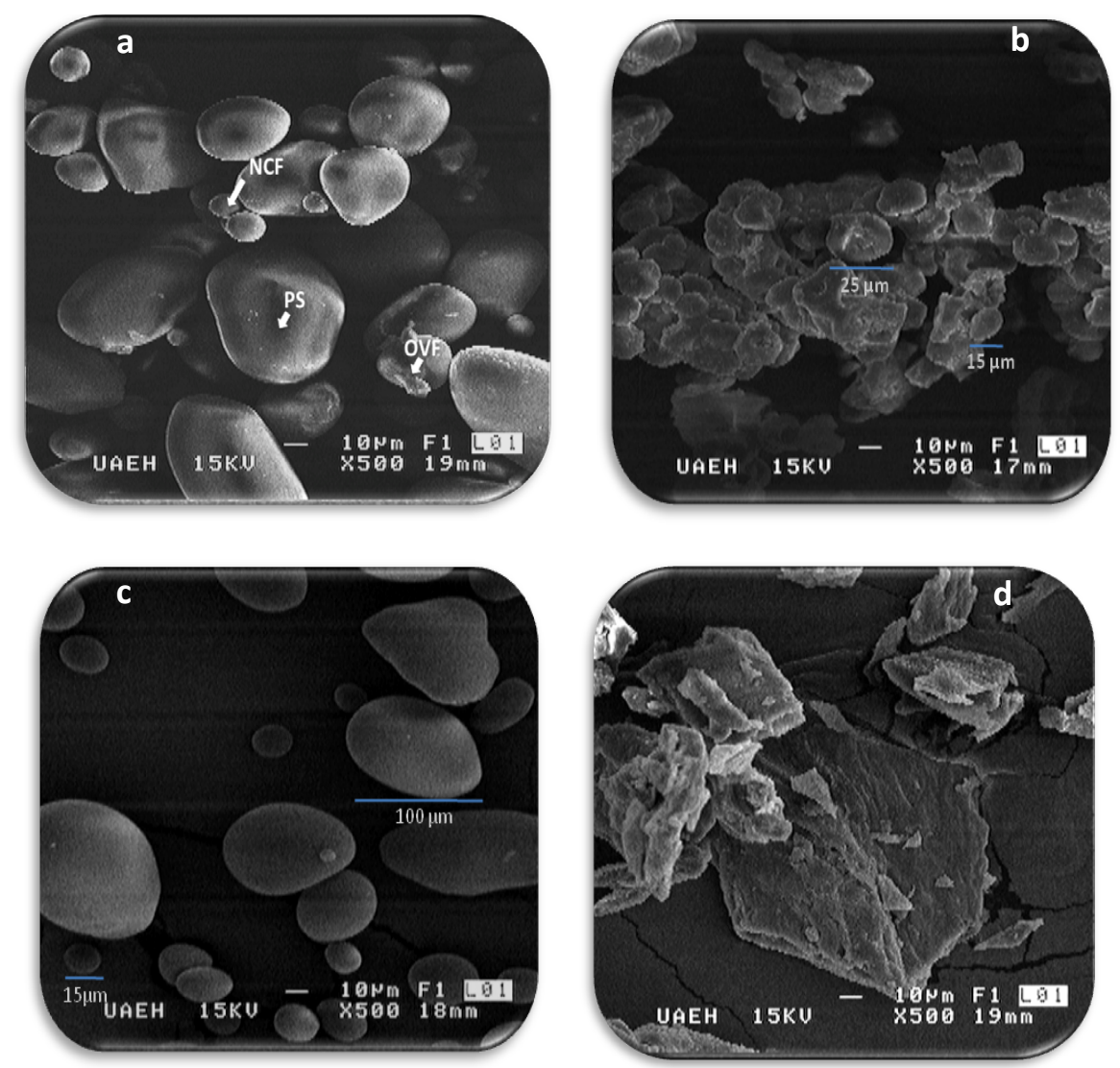

Figure 2: Scanning electron micrographs of (a) unprocessed mixture, (b) nixtamalized corn flour (NCF), (c) potato starch (PS), and (d) orange vesicle flour (OVF) used for the extrusion process.
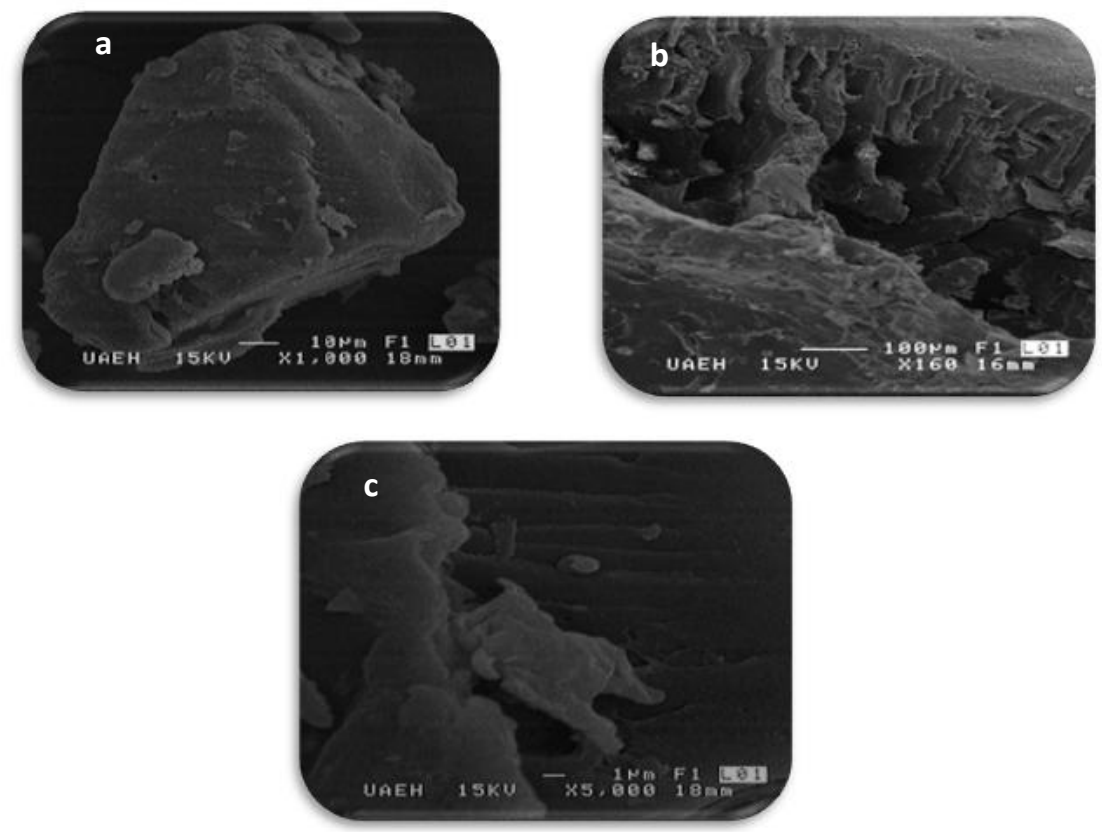

Figure 3: Scanning electron micrographs of milled extruded pellets obtained using the optimal processing conditions, $130{ }^{\circ} \mathrm{C}$ and $23 \%$ moisture content; a, b, and $\mathrm{c}$ correspond to different zones of the pellet. 
Citation: Tovar-Jímenez X, Aguilar-Palazuelos E, Gómez-Aldapa CA, Caro-Corrales JJ (2016) Microstructure of a Third Generation Snack Manufactured by Extrusion from Potato Starch and Orange Vesicle Flour. J Food Process Technol 7: 563. doi:10.4172/2157-7110.1000563
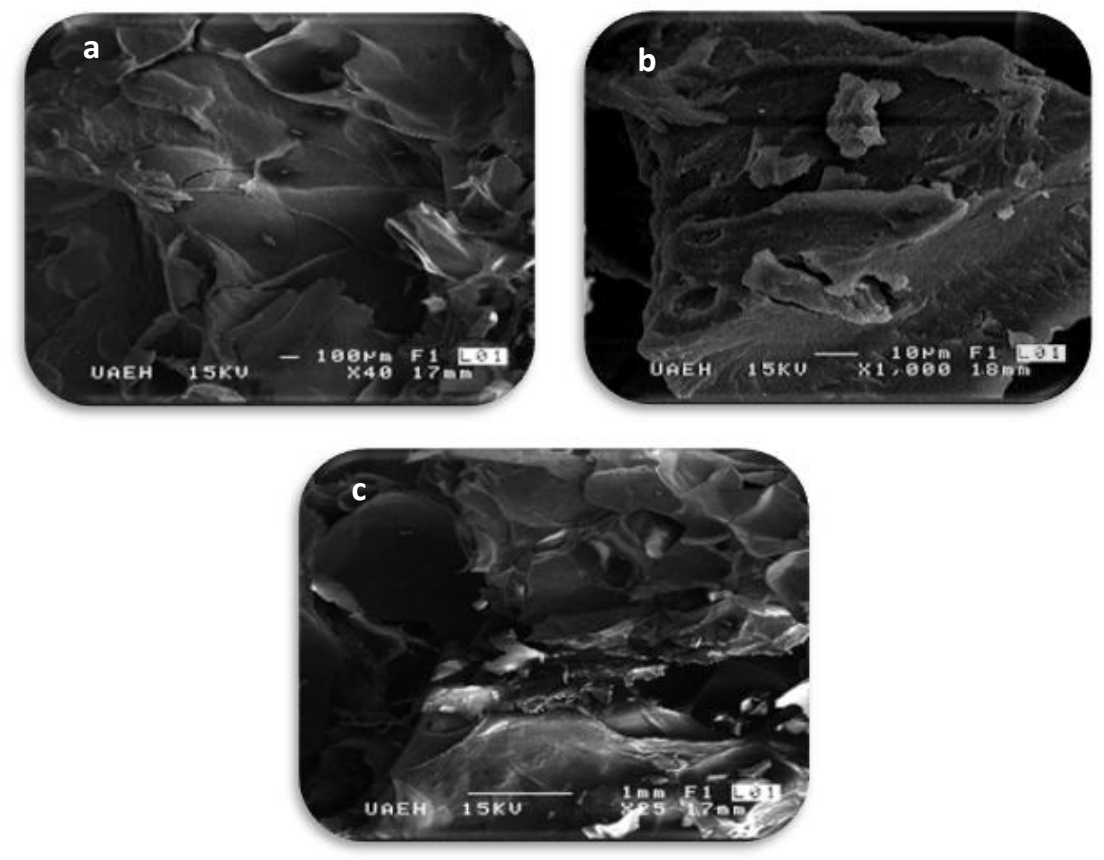

Figure 4: Scanning electron micrographs of the microwave expanded product; $a, b$, and c correspond to different zones of the expanded product.

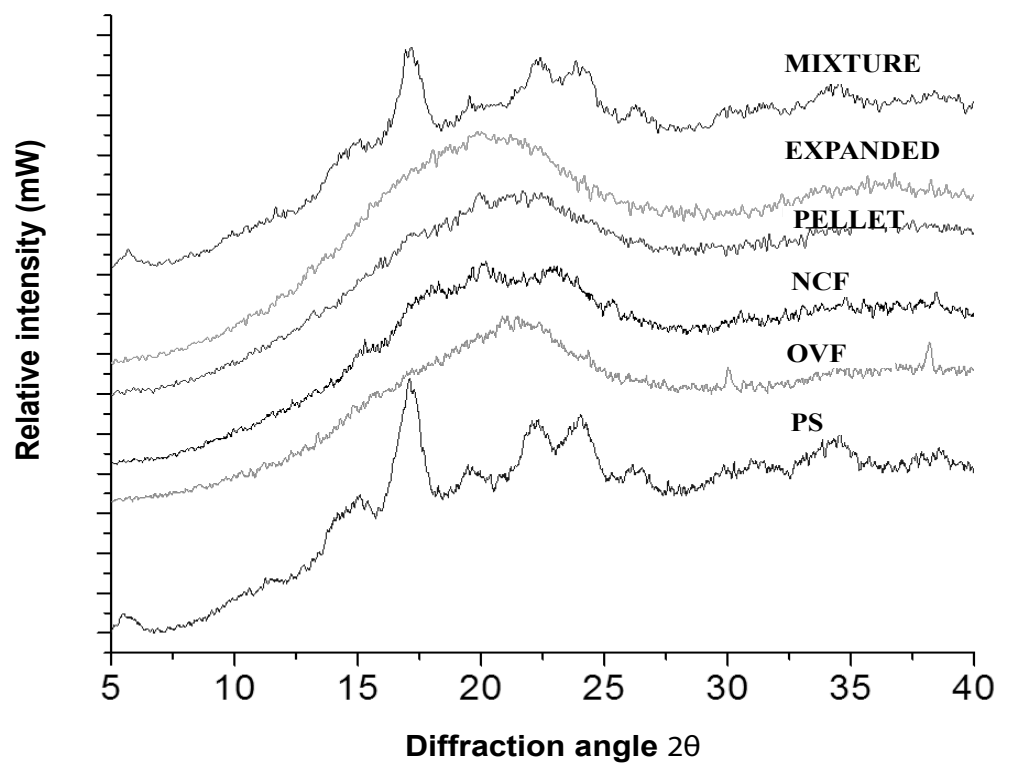

Figure 5: X-ray diffraction patterns of nixtamalized corn flour (NCF), potato starch (PS), orange vesicle flour (OVF), unprocessed mixture, extruded pellet, and microwave expanded product.

conditions are enough for modifying the native crystalline structure, but are not sufficient for the formation of new crystalline structures. Extrusion processing can partially or totally break the crystalline structure of starch, depending on the extrusion conditions such as moisture content, shear stress, and temperature. High temperatures can completely destroy starch structure, leading to the formation of an $\mathrm{X}$-ray diffractogram typical of an amorphous state or can induce the formation of a new structure [24]. During extrusion, extruded materials show large amounts of plasticized and slightly damaged granules [25].

\section{Differential scanning calorimetry}

The thermogram data of raw materials [nixtamalized corn flour (NCF), potato starch (PS), orange vesicle flour (OVF)], unprocessed mixture, extruded pellet, and microwave expanded product are shown in Table 2. Nixtamalized corn flour had temperatures of $65.2^{\circ} \mathrm{C}$ for onset $\left(T_{i}\right), 68.5^{\circ} \mathrm{C}$ for peak $\left(T_{g}\right)$, and $69.7^{\circ} \mathrm{C}$ for final temperature $\left(T_{f}\right)$, Potato starch and unprocessed mixture showed $59.5,63.7,69.5^{\circ} \mathrm{C}$ and $61.3,64.9,69.7^{\circ} \mathrm{C}$ for $T_{i}, T_{g}$, and $T_{\rho}$ respectively. Temperatures for 


\begin{tabular}{|c|c|c|c|c|}
\hline & $\mathbf{T}_{\mathbf{i}}\left({ }^{\circ} \mathbf{C}\right)$ & $\mathbf{T}_{\mathbf{g}}\left({ }^{\circ} \mathbf{C}\right)$ & $\mathbf{T}_{\mathbf{f}}\left({ }^{\circ} \mathbf{C}\right)$ & $\boldsymbol{\Delta} \mathbf{H}(\mathbf{m} \mathbf{J})$ \\
\hline NCF & 65.2 & 68.5 & 69.7 & $-15.8 \times 10^{-3}$ \\
\hline PS & 59.5 & 63.7 & 69.5 & -107.08 \\
\hline OVF & -- & -- & -- & - \\
\hline Mixture & 61.3 & 64.9 & 69.7 & -55.48 \\
\hline Pellet & -- & -- & -- & -- \\
\hline Expanded & -- & -- & -- & -- \\
\hline
\end{tabular}

(-- No gelatinization peak), $T_{\mathrm{i}}$ is initial temperature [onset], $T_{g}$ is gelatinization temperature, $T_{\mathrm{f}}$ is final gelatinization temperature [endset], and $\Delta^{g} H$ is the transition enthalpy.

Table 2: Thermogram data of raw materials [nixtamalized corn flour (NCF), potato starch (PS), orange vesicle flour (OVF)], unprocessed mixture, extruded pellet, and microwave expanded product.

mixture are similar to those found for potato starch, which is attributed to potato starch is the main component in the mixture. The transition enthalpy was 26.8 and $13.9 \mathrm{~J} \mathrm{~g}^{-1}$ for potato starch and unprocessed mixture. The orange vesicle flour, extruded pellet, and microwave expanded product did not show a significant gelatinization peak, which can occur because starch is gelatinized. These results agree with those reported by Maninder, et al. [26] and Aguilar-Palazuelos, et al. [11]. Lee et al. [27] reported that the degree of gelatinization of starch, extruded under critical conditions, was higher as the extrusion temperature was lowered. They found that the extrudates at $80^{\circ} \mathrm{C}$ showed a small peak of gelatinization, meanwhile, at 90 and $100^{\circ} \mathrm{C}$ no endothermic peak was found. In our study, extrusion was accomplished at $130^{\circ} \mathrm{C}$ and $23 \%$ moisture content and no gelatinization peak was observed in the extrudates.

\section{Conclusions}

The analyzed optimum processing conditions were adequate for producing a third-generation snack from a mixture of corn starch and orange vesicle flour. These raw materials are a promising material for production of third-generation snacks and the analyses of the X-ray diffractograms, viscosity profiles, scanning electron microscopy and differential scanning calorimetry suggested that the extruded products presented changes mainly due to fragmentation, gelatinization and plasticization of the starch granule, causing the loss of the granular starch (modification in its native structure). The snacks obtained by the extrusion process and expanded by microwave were modified to a desirable microstructure for achieving adequate physicochemical properties for acceptance by the consumer.

\section{References}

1. Manrique-Quevedo N, Gonzales-Soto RA, Othman-Abn-Hardan M, GarciaSuarez FJ, Bello-Perez LA (2007) Characterization of pregelatinized blends of mango and banana starches with different extrusion conditions. Rev Agrociencia 41: 637- 645

2. Cheftel JC (1986) Nutritional effects of extrusion cooking. Food chem 20: 263-283.

3. Gimeno E, Moraru Cl, Kokini JL (2004) Effect of xanthan gum and CMC on the structure and texture of corn flour pellets expanded by microwave heating. Cereal Chem 81: 100-107.

4. Lee EY, Lim KII, Lim JK, Lim ST(2000) Effects of gelatinization and moisture content of extruded starch pellets on morphology and physical properties of microwave-expanded products. Cereal Chem 77: 769-773.

5. Ding QB, Ainsworth P, Plunkett A, Tucker G, Marson H (2006) The effect of extrusion conditions on the functional and physical properties of wheat-based expanded snacks. J Food Eng 73: 142-148.

6. Vasanthan T, Yeung J, Hoover R (2001) Dextrinization of starch in barley flours with termostable alpha-amylase by extrusion cooking. Starch-Starke 53: 616- 622

7. Larrea CMA, Chang YK, Martinez-Bustos F (2005) Effect of some operational extrusion parameters on the constituents of orange pulp. Food Chem 89: 301-308

8. Hernández-Díaz JR, Quintero-Ramos A, Barnard J, Balandran-Quintana RR (2007) Functional properties of extrudates prepared with blends of wheat flour/ pinto bean meal with added wheat bran. Food Sci Technol Int 13: 301-308.

9. Larrea CMA, Martínez-Bustos F, Yoon KC (2010) The effect of extruded orange pulp on enzymatic hydrolysis of starch and glucose retardation index. Food Bioprocess Technol 3: 684- 692

10. Tovar-Jiménez X, Caro-Corrales J, Gómez-Aldapa CA, Zazueta-Morales J, Limón-Valenzuela $V(2015)$ Third generation snacks manufactured from orange by-products: physicochemical and nutritional characterization. J Food Sci Technol 52: 6607-6614.

11. Aguilar-Palazuelos E, Zazueta-Morales JJ, Martínez-Bustos F (2006) Preparation of high-quality protein-based extruded pellets expanded by microwave oven. Am Assoc Cereal Chem 83: 363-369.

12. Zeng M, Morris CF, Batey IL, Wrigley CW (1997) Sources of variation for starch gelatinization pasting, and gelation properties in wheat. Cereal Chem 74: 63-71.

13. Zazueta-Morales JJ, Martínez-Bustos F, Jacobo-Valenzuela N, OrdoricaFalomir C, Paredes-López O. (2002) Effects of calcium hydroxide and screw speed on physicochemical characteristics of extruded blue maize. J Cereal Sci 67: 3350-3358.

14. Aguilar-Palazuelos E, Zazueta-Morales JDJ, Jiménez-Arévalo OA, MartínezBustos F (2007) Mechanical and structural properties of expanded extrudates produced from blends of native starches and natural fibers of henequen and coconut. Starch-Stärke 59: 533-542.

15. Toro-Vázquez J, Herrera-Coronado V, Dibildox-Alvarado E, Charo-Alonso M, Gómez-Aldapa C. (2002) Induction time of crystallization in vegetable oils comparative measurements by differential scanning calorimetry and diffusive light scattering. J Food Sci 67: 1057-1064.

16. Salinas-Moreno Y, Herrera-Corredor JA, Castillo-Merino J, Pérez-Herrera P (2003) Cambios físico-químicos del almidón durante la nixtamalización de maíz en variedades con diferente dureza de grano. Arch Latinoam Nutr 53 : 188-193.

17. Alvis A, Vélez CA, Villada HS, Rada-Mendoza M (2008) Análisis físico-químico y morfológico de almidones de ñame, yuca y papa y determinación de la viscosidad de las pastas. Inf Tecnol 19: 19-28.

18. Hoover R (2001) Composition molecular structure and physicochemical properties of tuber and root starches: A review. Carbohydrate Polymers 5: 253- 67.

19. Carvalho RV, Ascheri JLR, Cal-Vidal J (2002) Efeito dos parâmetros de extrusão nas propriedades físicas de pellets $(3 G)$ de misturas de farinhas de trigo arroz e banana Ciência Agrotecnica Lavras 26: 1006-1018.

20. Delgado-Nieblas C, Aguilar-Palazuelos E, Gallegos-Infante A, Rocha-Guzmán $\mathrm{N}$, Zazueta-Morales JJ, et al. (2012) Characterization and optimization of extrusion cooking for the manufacture of third-generation snacks with winter squash (Cucurbita moschata d.) flour. Am Assoc Cereal Chem 89: 65-72.

21. Medina JA, Salas JC (2008) Morphological Characterization of Native Starch Granule: Appearance, Shape, Size and its Distribution. Rev Ing 27: 56-62.

22. Asp NG, Bjorck I (1989) Nutritional properties of extruded foods. En: Extrusion cooking. Mercier C Linko P y Harper JM (Eds) Am Assoc Cereal Chem Inc St Paul MN USA 14: 399-434.

23. Moraru Cl, Kokini JL (2003) Nucleation and expansion during extrusion and microwave heating of cereal foods. Compr Rev Food Sci F 2: 120-138.

24. McPherson AE, Bailey TB, Jane J (2000) Extrusion of crosslinked hydroxypropylated corn starches I. Pasting properties. Cereal Chem 77: 320-325.

25. Della-Valle G, Vergnes B, Colonna P, Patria A (1997) Relations between rheological properties of molten starches and their expansion behaviour in extrusion. J Food Eng 31: 277-296.

26. Maninder K, Narpinder S, Kawaljit SS, Harmeet SG (2004) Physicochemical morphological thermal and rheological properties of starches separated from kernels of some Indian mango cultivars (Mangifera indica L.) Food Chem 85 131-140.

27. Lee EY, Ryu GH, Lim ST (1999) Effects of processing parameters on physica properties of corn starch extrudates expanded using supercritical $\mathrm{CO}_{2}$ injection. Cereal Chem 76: 63-69. 